\title{
Mantle sources for basalt and kimberlite rocks bodies with differing age in the Nyurbinskaya pipe (Nakyn field, Yakutia)
}

\author{
Sergey M. Sablukov ${ }^{1}$, Liudmila I. Sablukova ${ }^{1}$, Yury B. Stegnitsky ${ }^{2}$ and Valery I. Banzeruk ${ }^{3}$ \\ ${ }^{1}$ RUSGEO Ltd, Moscow, Russia, \\ ${ }^{2}$ YaNIGP TsNIGRI ALROSA Co. Ltd., Mirny, Russia, \\ ${ }^{3}$ Nyurbinskaya Mine ALROSA Co. Ltd., Mirny, Russia
}

Nakyn field kimberlites differ drastically from kimberlites of other Yakutian kimberlite fields (Tomshin et al., 1998), primarily, by being free of picroilmenite and extremely geochemically depleted, with peculiarly low concentration of $\mathrm{Ti}, \mathrm{Fe}$ and all incompatible elements except for $\mathrm{K}, \mathrm{Rb}$ and $\mathrm{P}$. These sharp distinctions may be related to different intrusion age of kimberlites in different fields reflecting the particular condition of the mantle characteristic of its different evolution stages.

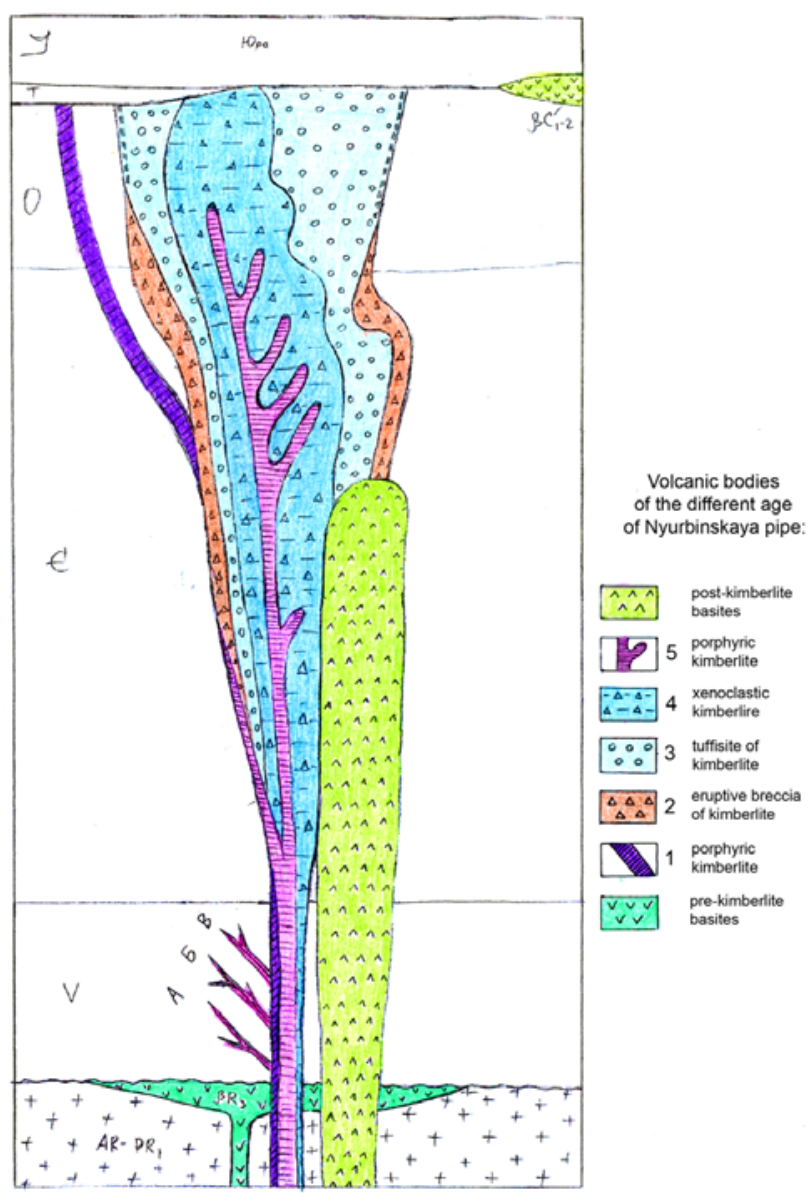

Model of structure of the Nyurbinskaya pipe (section)
A series of $\mathrm{Sm}-\mathrm{Nd}, \mathrm{Rb}-\mathrm{Sr}$ and $\mathrm{K}-\mathrm{Ar}$ isotope studies revealed a significantly older kimberlite intrusion age $\left(\mathrm{D}_{1} \mathrm{em}, 399 \pm 4.6 \mathrm{Ma}\right.$, Sablukov et al, 2007) and an older model age of mantle source $\left(\mathrm{T}_{\mathrm{Nd}}(\mathrm{DM})=1100 \mathrm{Ma}, \varepsilon \mathrm{Nd}\right.$ $=+1.0, \varepsilon \mathrm{Sr}=+25.2$ ) for Nyurbinskaya pipe as compared to other diamondiferous kimberlites of the Yakutian province $\left(\mathrm{D}_{3}-\mathrm{C}_{1}, 370-320 \mathrm{Ma}\right.$, Brakhfogel, 1995; $\mathrm{T}_{\mathrm{Nd}}(\mathrm{DM})=0.6-0.7 \mathrm{Ga}$, Bogatikov et al., 2004).

A peculiar feature of the Nyurbinskaya pipe consists in the joint presence of a pre-kimberlite dolerite intrusion (xenoliths of which occur in pipe kimberlites) and a post-kimberlite dolerite intrusion (penetrating the kimberlites) in the Nyurbinsky volcanic complex.
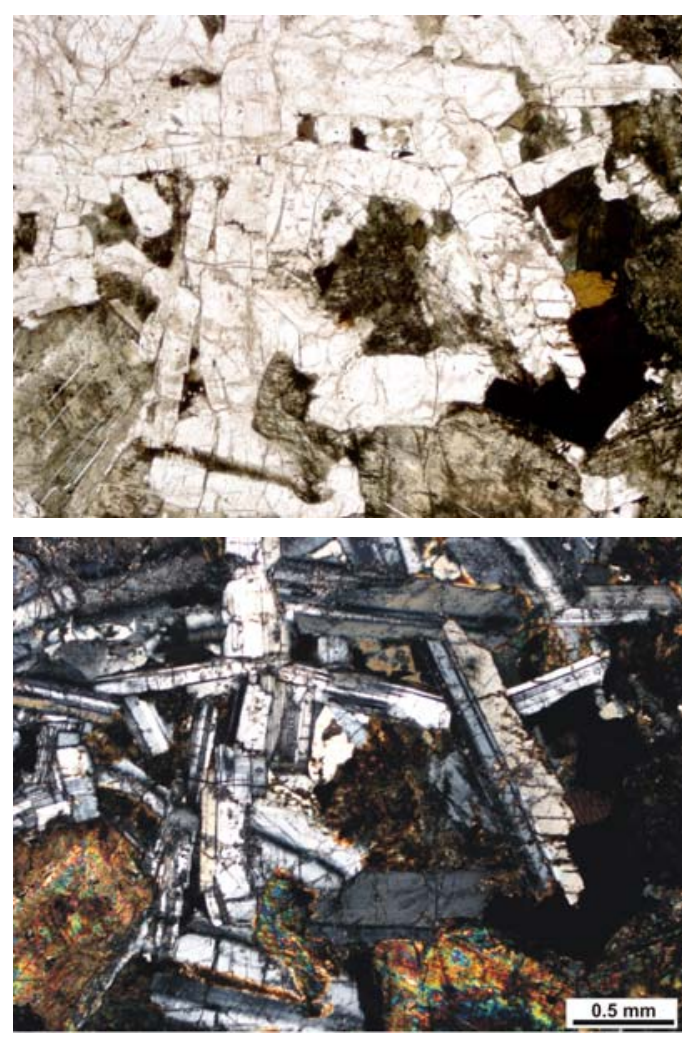

Pre-kimberlite dolerite, think section: plane light (top) and cross-polarized light (bottom). 

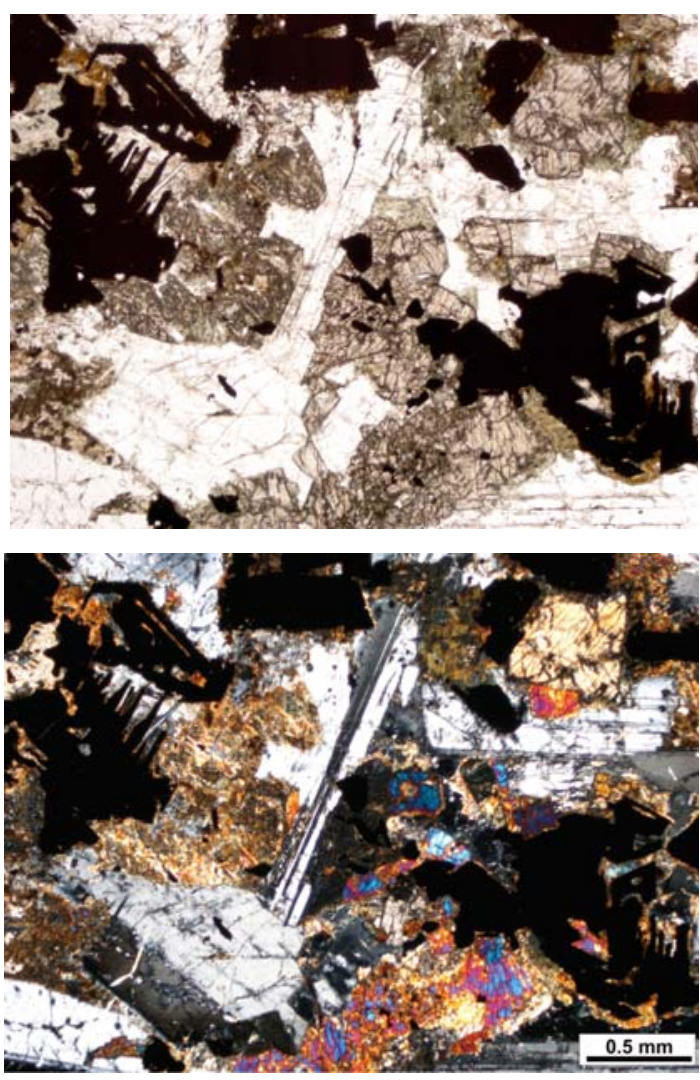

Post-kimberlite dolerite, think section: plane light (top) and cross-polarized light (bottom).

Our investigation revealed that petrographically similar but obviously nonsynchronous mafic volcanic rock bodies (separated from each other by the kimberlite intrusion stage) show not simply dissimilar but radically differing geochemical characteristics. Only $\mathrm{SiO}_{2}, \mathrm{Na}_{2} \mathrm{O}, \mathrm{K}_{2} \mathrm{O}$ and $\mathrm{Co}$ contents of pre-kimberlite and post-kimberlite dolerites are somewhat similar. Prekimberlite dolerites are 1.5 times higher in $\mathrm{Al}_{2} \mathrm{O}_{3}$ and $\mathrm{MgO}, 2$ to 3 times higher in $\mathrm{Ba}$ and $\mathrm{Pb}, 5$ times higher in $\mathrm{Ni}$ and $15($ !) times higher in $\mathrm{Cr}$ as compared to postkimberlitic dolerites. Along with this, post-kimberlitic dolerites are richer than the pre-kimberlitic ones in the overwhelming majority of elements: FeOtot, $\mathrm{CaO}, \mathrm{Be}$, $\mathrm{V}, \mathrm{Ga}, \mathrm{Rb}, \mathrm{Cs}, \mathrm{Sr}$, (by a factor of 1.5-2.5), $\mathrm{TiO}_{2}, \mathrm{MnO}$, $\mathrm{P}_{2} \mathrm{O}_{5}, \mathrm{Cu}, \mathrm{Zn}, \mathrm{Y}, \mathrm{Zr}, \mathrm{Hf}, \mathrm{REE}, \mathrm{Th}, \mathrm{U}$, (by a factor of 3 to 6), and more than ten times richer in $\mathrm{Nb}$ and $\mathrm{Ta}$ ! Normalized REE distribution for volcanic rocks (Boynton, 1984) show Eu-maximum for the prekimberlite basites and Eu-minimum for the postkimberlite basites.

The most prominent geochemical features of the prekimberlitic ("old") mafic rocks of the Nyurbinskaya pipe are their significantly lower $\mathrm{Ti}$ and $\mathrm{Fe}$ contents and higher $\mathrm{Al}$ content as compared to those of the postkimberlitic ("young") mafic rocks of this pipe.

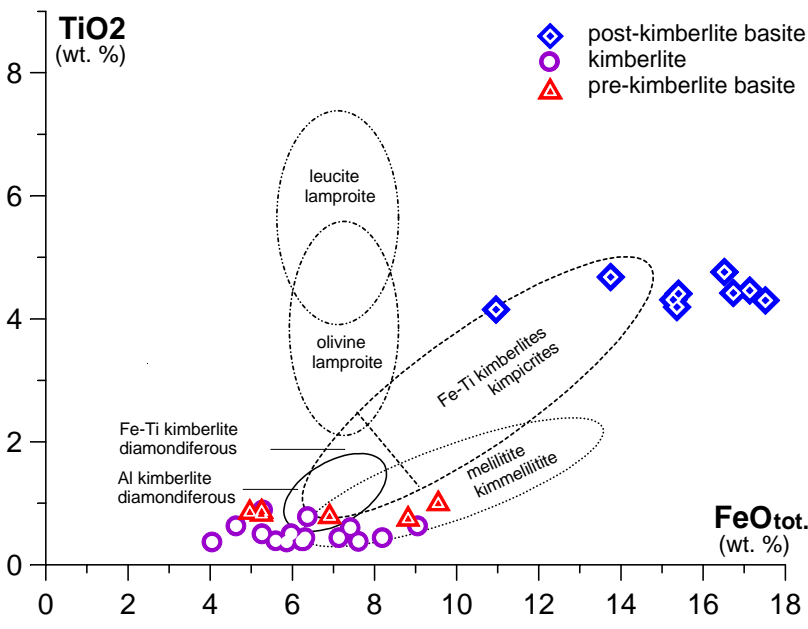

Chemical compositions of the volcanic rocks

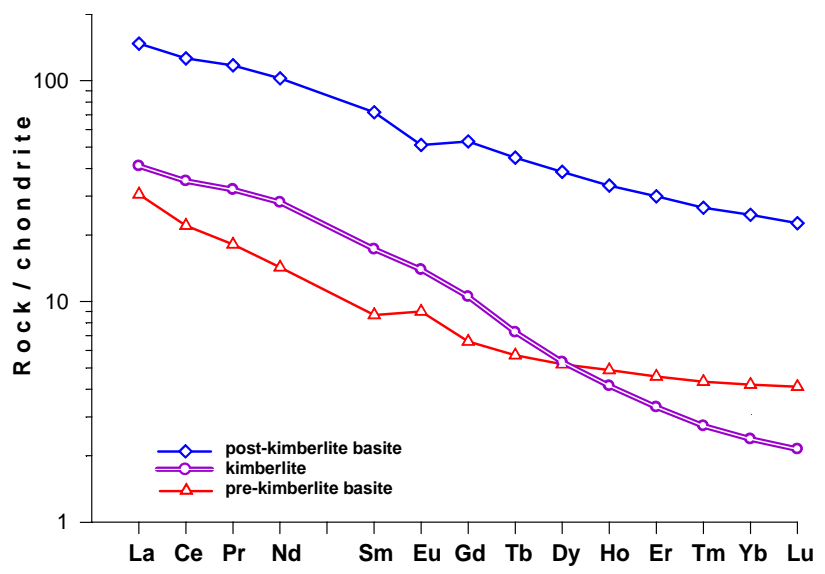

Normalized REE distribution for volcanic rocks (Boynton, 1984).

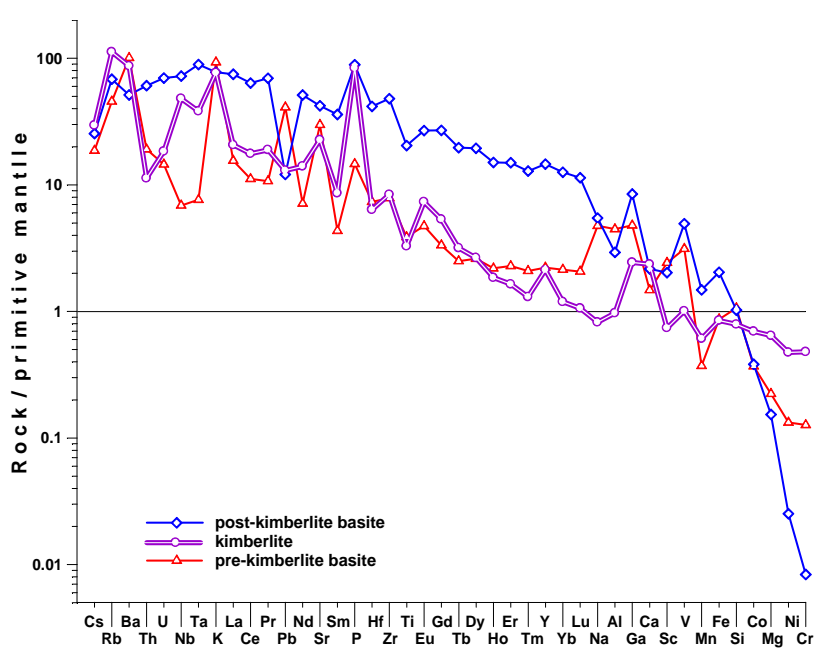

Normalized element distribution from volcanic rocks (McDonough et al., 1992; Jagoutz et al., 1979)

Geochemically, the pre- kimberlite dolerite of this pipe is close to high-Al calc-alkali basalt rocks of volcanic arc in subduction zones, the post-kimberlite dolerite is 
similar to sharply geochemically enriched, high-Fe within-plate tholeitic basalt rocks, and kimberlites correspond to within-plate alkaline basalt rocks (Wood, 1980).

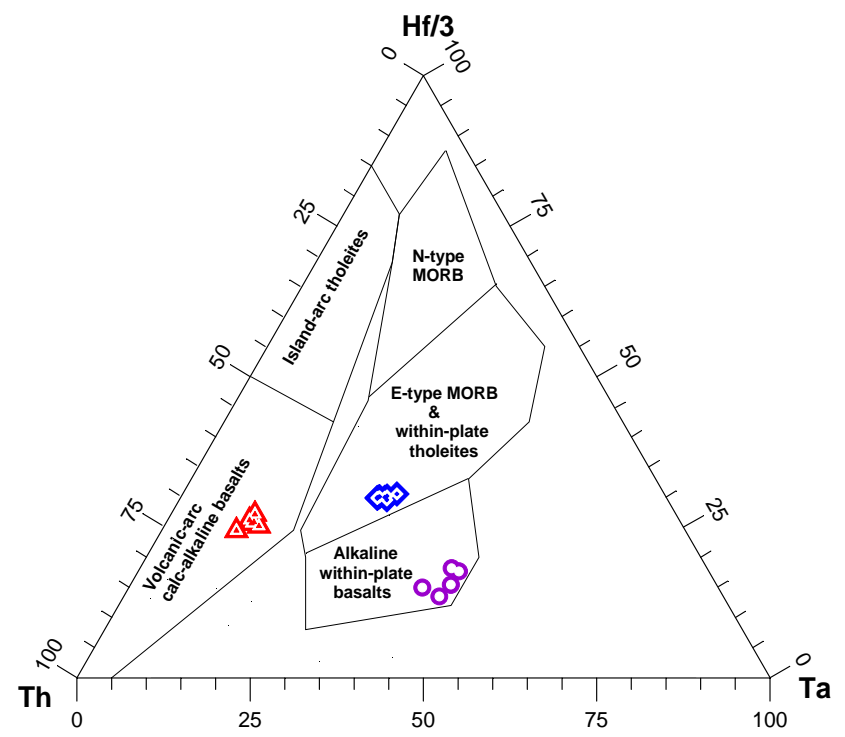

Element distribution from volcanic rocks (Wood, 1980).

According to $\mathrm{K}-\mathrm{Ar}$ and $\mathrm{Rb}-\mathrm{Sr}$ dating, the prekimberlite dolerite is Late Riphean (700 Ma), and the post-kimberlite dolerite is Middle Carboniferous (330 $\mathrm{Ma})$. As regards the age and type of mantle source, the pre-kimberlite dolerite appears to be related to old, enriched lithospheric mantle, with probable participation of some old lower crust matter (EMII, $\left.\varepsilon \mathrm{Nd}=-12.2, \varepsilon \mathrm{Sr}=+54.6 ; \mathrm{T}_{\mathrm{Nd}}(\mathrm{DM})=2450 \mathrm{Ma}\right)$, whereas the post-kimberlite dolerite would be related to depleted mantle with probable participation of young upper crust matter $\left(\varepsilon N d=+4.7, \varepsilon \mathrm{Sr}=+43.7 ; \mathrm{T}_{\mathrm{Nd}}(\mathrm{DM})\right.$ $=770 \mathrm{Ma})$.

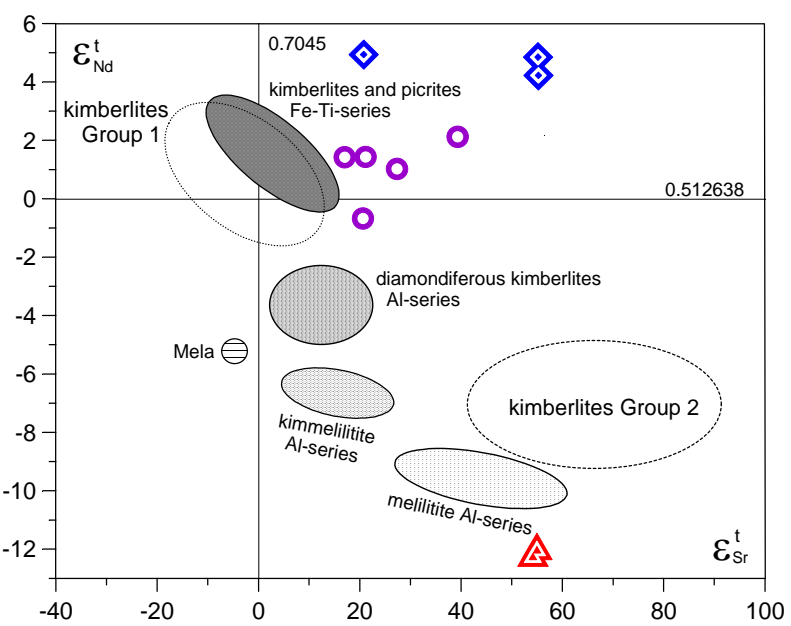

$\mathrm{Sr}$ and $\mathrm{Nd}$ isotope composition of the volcanic rocks from the Nyurbinskaya pipe in comparison by volcanic rocks of Zimni Bereg (Arkhangelsk province)

The different volcanic rocks with differing age incorporated in the Nyurbinskaya pipe represent a The different volcanic rocks with differing age incorporated in the Nyurbinskaya pipe represent a "record" of temporal evolution for mantle sources of mafic and ultramafic magmatic melts, from the Late Riphean to the Middle Carboniferous.

Time of formation pre-kimberlite dolerite (Late Riphean) is a time of cardinal tectonic reorganization of Northern Asia, when approximately on a boundary $700 \mathrm{Ma}$ under influence of riftogenes processes there was a split of the supercontinent Rodinija including as a component Siberian kraton (Yarmoluk et al., 2003).

The prominent geochemical distinctions between the "old" and "young" dolerites in the Nyurbinskaya pipe, concurrent with the well defined geochemical dissimilarity between the relatively old Nyurbinskaya pipe kimberlites and relatively young kimberlites from other Yakutian kimberlite fields (high $\mathrm{Fe}$ and $\mathrm{Ti}$ contents and similarity of composition and model age of mantle sources for the relatively young magmatic rocks) might be caused by some geological process of common type. The role of such a global geological process, which could sharply change (at least) the geochemical characteristics of the upper mantle and give rise to intense Fe-Ti mantle metasomatism, could be played by a Late Devonian asthenospheric diapir (plume). The relatively old mafic rocks and pre-plume kimberlites might reflect the composition of old, geochemically depleted lithospheric mantle, whereas the relatively young mafic rocks and post-plume kimberlites appear to reflect the composition of the heterogeneously metasomatized geochemically enriched (owing to the plume effect) upper mantle.

\section{References}

Bogatikov O.A., Kononova V.A., Golubeva J.J. etc., 2004. Petrogeochemic and isotope variations of composition kimberlites from Yakutia and their reason. // Geochemistry, 9, 915-939.

Sablukov S.M., Banzeruk V.I., Sablukova L.I., Stegnitskij Ju.B., Bogomolov E.S., Lebedev V.A., 2007. Ancient age of the Nakyn field kimberlites (Yakutia) - one of the reasons of an originality of their material structure // VIII International conference «New ideas in sciences about the Earth». Moscow. Reports. T. 5, 209212.

Tomshin M.D., Fomin A.S., Kornilova V.P., Cherny S.D. and Yanygin Ju.T., 1998. Feature of magmatic formations Nakyn kimberlite fields of the Yakutia province // Geology and Geophysic, T.39, 12, 1693-1703.

Yarmoluk V.V., and Kovalenko V.I., 2003. Mantle plumes in phanerozoic history of the Northern Asia// Plumes and problems of deep sources of alkaline magmatism. Proceedings of the III Interntional Conference. Khabarovsk. Publishing House of the Irkutsk State Technical University, 5-35. 